\section{Comparison of the Postharvest Quality of Noble Fir Boughs from the United States and Danish Provenances Grown in Denmark}

\author{
Gary A Chastagner ${ }^{1}$
}

Washington State University Research and Extension Center, Puyallup, WA 98371

Ulrik Bräuner Nielsen ${ }^{2}$

Danish Forest and Landscape Research Institute, Hørsholm Kongevej 11, DK-2970 Hørsholm, Denmark

\section{Kathleen L. Riley}

Washington State University Research and Extension Center, Puyallup, WA 98371

Additional index words. Abies procera, Christmas trees

Abstract. Postharvest moisture and needle retention of boughs was examined for four Danish and five U.S. provenances of noble fir grown in Denmark. Boughs were displayed indoors under controlled conditions, and data were collected relating to rates of moisture loss and needle retention. Small current-year shoots had moisture and needle loss patterns similar to larger bough material. Postharvest quality of the Danish and U.S. provenance boughs was very similar. There was also a high correlation between the moisture level of the boughs and shoots, indicating that it should be possible to use small shoots to assess differences in moisture retention in future tests.

Noble fir (Abies procera Red.) has become one of the most important conifer species used for the production of high-quality Christmas tree and bough products in Europe and North America (Chastagner and Benson, 2000; Davidson, 1999; Frampton and McKinley, 1999). In Europe, Denmark produces an estimated 9.5 $\times 10^{6}$ Christmas trees that when combined with 25,000 tons of bough material has an estimated value of \$120 million (KajØstergaard, persona communication). This represents nearly half of the total revenue from all forest products produced in Denmark (Danmarks statistik 2000). Although nordmann fir (Abies nordmanniana (Stev.) Spach.) accounts for most of the Danish Christmas tree production, noble fir makes up the majority of the Danish bough material and most of the new Christmas tree production in Ireland.

Growers in the western portions of Oregon and Washington in the Pacific Northwest (PNW) supply about one-third of the $36 \times 10^{6}$ Christmas trees sold annually in the United States. Noble fir has rapidly become the most important Christmas tree in the PNW, now accounting for $\approx 45 \%$ of the total production.

Received for publication 6 Dec. 2002. Accepted for publication 28 July 2003. Plant Pathology New Series No. 0348, Project WNP0388, Dept. of Plant Pathology, College of Agriculture and Home Economics, Wash. State Univ., Pullman. The USDA FAS, ICD, RSED Scientific Cooperation Program, Pacific Northwest Christmas Tree Association, and the Danish Production Fee Foundation for Christmas Trees and Greenery supported portions of this work Special thanks to Langes $\emptyset$ Estate for providing the plant material used in these studies.

ee-mail chastag@wsu.edu.

2e-mail ubn@fsl.dk.
The value of Christmas trees produced in the PNW is estimated to be about $\$ 120$ million. An estimated 20,000 tons of noble fir boughs were harvested in the PNW during 2002 (Mark Savage, personal communication). The 2002 wholesale-retail value of noble fir boughs is estimated to range from $\$ 18$ to $\$ 30$ million. In the United States, the production of noble fir Christmas trees and boughs is largely limited to the PNW.

Noble fir is one of the highest quality Christmas trees available on the market. When displayed in water at $20^{\circ} \mathrm{C}$, this species maintains high moisture levels with very little needle loss for at least 6 weeks (Chastagner and Riley, 2003). Noble fir and, to a lesser extent, fraser fir (A. fraseri (Pursh) Poir.) are unique among Abies spp. that are commonly grown for Christmas trees and bough material in that they rarely lose any needles as they dry (Chastagner and Riley, 2003; Hinesley, 1984; Hinesley and Snelling, 1995).

Noble fir is native to the mountainous areas of western Oregon and Washington. It was introduced into Denmark in the middle of the 19th century from the PNW, and Denmark has been producing seed to meet their needs since

Table 1. Noble fir provenances tested.

\begin{tabular}{lll}
\hline Source & Number & Provenance \\
\hline Danish & 16 & Frijsenborg, Hagsholm dept. 314, approval no. F.480 \\
& 44 & Overgaard, Overgaard dept. 2 \\
& Ulborg, Fejso dept. 514, approval no. F.587 \\
& Rye,Norskov dept. 315, approval no. F.479 \\
& 90 & \\
& & Mt. St. Helens, seed zone 440, elev. 3500 ft \\
United States & 84 & West Centralia, seed zone 241, elev. 3500 ft \\
& 86 & Old Baldy Mt., seed zone 421, elev. 3500 ft \\
& 87 & Cowlitz Randle, seed zone 430, elev. $3000 \mathrm{ft}$ \\
& 88 & Mary's Peak, seed zone 252, elev. 3500 ft \\
\hline
\end{tabular}
1995, 1997). Several U.S. nurseries are selling the 1930s (Barner et al., 1980). Since the mid 1960 s, extensive selection has been done in Denmark by collecting seed from trees that have exhibited desirable frost tolerance, fullness, color, needle length, lateral branching, and bough shape (Barner et al., 1980; Larsen, 1985; and Nielsen, 1994). Today, there are $\approx 50$ approved Danish seed sources (stands) and there are several third generation seed sources (Plantedirektoratet, 2001) in Denmark.

Expansion of noble fir production in the PNW is limited to some extent by the susceptibility of many of the commonly grown seed sources to the physiological disorder known as current season needle necrosis (CSNN), which occurs on noble fir in North America, Ireland, and Denmark (Chastagner and Benson, 2000). In Denmark, the condition is also referred to as røde nåle på nobilis (red needles on noble fir) (Nielsen and Christensen 1995,1997).

There is increasing evidence from the PNW and Denmark that the development of CSNN is under strong genetic control. Seed from noble fir trees in the Riley-Fanno area of coastal Oregon consistently produce high quality Christmas trees over a range of sites in the PNW (Brown, 1990; Brown and Landgren, 1995; Douglas, 1984), but there is considerable variation in the development of CSNN on different families (Chastagner and Landgren 1998). Even though they were originally from the PNW, many of the highly selected Danish sources of noble fir have limited susceptibility to CSNN and studies in Denmark have shown that selected noble fir provenances from Oregon and Washington are more prone to CSNN than Danish provenances (Nielsen and Christensen noble fir seed or seedlings from some of these Danish sources.

Given the limited susceptibility of some Danish selections of noble fir to CSNN, there is an increasing interest among growers to plant Danish noble fir in the PNW and Ireland. Although genetic variation has been studied in relation to a number of important traits that are important to Christmas tree and bough growers (Brown, 1990; Brown and Landgren, 1995; Doede and Adams, 1998; Douglas, 1984; Larsen, 1985; Nielsen et al., 1989; Roulund and Jensen, 1990), testing is needed to determine the variability in postharvest moisture and needle retention characteristics between Danish sources and material from U.S. provenances to ensure that these sources have similar postharvest quality as the U.S. provenances. Our objectives were to 1) compare the postharvest moisture and needle retention 


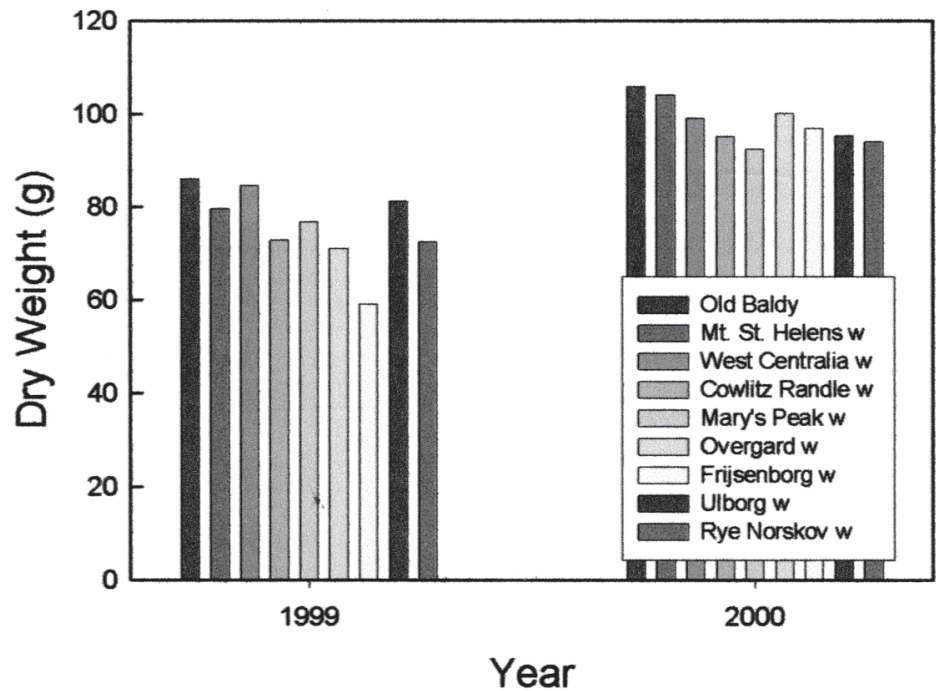

Fig. 1. Dry weights of two-cross branches from U.S. and Danish provenances of noble fir during 1999 and 2000 .

Table 2. Analysis of variance results for overall moisture contents during noble fir provenance display trials in 1999 and 2000.

\begin{tabular}{|c|c|c|c|c|}
\hline \multirow[b]{2}{*}{ Source } & \multicolumn{2}{|c|}{1999} & \multicolumn{2}{|c|}{2000} \\
\hline & F value & Significance & F value & Significance \\
\hline Origin (Danish vs. U.S.) & 21.56 & $* *$ & 8.02 & $*$ \\
\hline Site (Forest vs. Farm) & 1.86 & NS & 3.32 & NS \\
\hline Limb (3-cross branch vs. shoot) & 37.80 & ** & 30.31 & $* *$ \\
\hline Origin $\times$ limb & 4.19 & NS & 0.05 & NS \\
\hline Site $\times \operatorname{limb} \times$ origin & 0.07 & NS & 4.19 & NS \\
\hline Day & 2447.72 & $* *$ & 1006.46 & $* *$ \\
\hline Origin $\times$ day & 1.29 & ns & 2.70 & ns \\
\hline Site $\times$ day $\times$ origin & 2.17 & ns & 2.76 & $*$ \\
\hline
\end{tabular}

characteristics of selected Danish and PNW provenances of noble fir growing in Denmark and 2) determine if small current-year shoots had moisture and needle loss patterns similar to larger boughs.

\section{Materials and Methods}

Experiments were conducted during October 1999 and 2000 to determine if there were significant differences in the rates of moisture and needle loss from noble fir boughs harvested from U.S. and Danish provenances of noble fir trees at two sites at the Langes $\varnothing$ Estate, $15 \mathrm{~km}$ west of Odense, Denmark. One of the sites is a former farm and the other is a former forest and is located $\approx 3 \mathrm{~km}$ from the farm site. These provenance plots consist of two replicated blocks of trees from five U.S. and four Danish provenances at each site (Table 1). Plots were established in Spring 1988 using 2/1 bareroot seedlings planted in a randomized complete block design with two replications of 24 trees per provenance at each site. Each replication consisted of a $4 \times 6$ group of trees planted on a $1.5 \times 1.5 \mathrm{~m}$ spacing. Weed control and fertilization was done according to commercial standards.

To determine if there were any differences in the rates of moisture and needle loss from these different sources of trees, a single 4-year-old branch was harvested from five trees of each provenance in each replication on 1 Oct. 1999 and 5 Oct. 2000. The branches were tagged, bundled together and transported back to the Danish Forest and Landscape Research Institute in a covered trailer, and stored outdoors overnight. The following day, the branches were trimmed to a two-cross branch (i.e., 2 years of growth) and a number of small current-year shoots. The two-cross branches were hung on sticks suspended across the postharvest display room. Branches were arranged on the sticks based on the blocking pattern used in the field. The current-year shoots from each branch were placed in the cells of a standard plastic 48-cell greenhouse propagation tray. These trays were placed just below the branches in the display room to compare the rate of moisture and needle loss from small shoot samples with the larger branches that were more representative of branches harvested for commercial greenery products.

The display rooms were $3.2 \mathrm{~m}$ long $\times 5.0 \mathrm{~m}$ wide $\times 3.4 \mathrm{~m}$ high. There were two fans $(45 \mathrm{~cm}$ in diameter), with plastic convection tubing that ran the length of the room, that were mounted underneath two tables covered with hardware cloth to provide continuous air circulation in the room. Room temperature and relative humidity were maintained at $20{ }^{\circ} \mathrm{C}$ and $45 \%$ to $55 \%$, respectively. Temperature and relative humidity were measured using a hygrothermograph calibrated with a sling psychrometer.

Changes in moisture levels were monitored for up to $11 \mathrm{~d}$ by determining the percent moisture content of the shoots and branches during the display period. Moisture content data for the branches was obtained by removing a small current-year shoot from the branch on each sampling date. For the current-year shoots in the tray, a single shoot was removed from the tray on each sampling date. The weight of these samples was measured prior to drying at $100{ }^{\circ} \mathrm{C}$ for $24 \mathrm{~h}$. Branches and shoots were also examined for needle loss by gentling rubbing the needles. Differences in the relative size of the branches between provenances and sites were determined by comparing the dry weights $\left(24 \mathrm{~h}\right.$ at $\left.100^{\circ} \mathrm{C}\right)$ of the branches upon completion of the experiment.

Statistical analysis of the dry weights of the branches and changes in moisture content of the branches and shoots during the display period were carried out using plot means. The statistical program SAS version 8 (SAS Institute, Cary, N.C.) was used for analysis of variance. The GLM procedure and the REPEATED option were used for repeated measurement analysis.

\section{Results}

Based on the dry weights of the harvested branches, there was no significant difference between the sizes of the branches harvested from the trees at the farm $(74 \mathrm{~g})$ and forest site (78 g) in 1999. In 2000, branches from the farm site were significantly $(P=0.05)$ lighter than branches from the forest site $(90$ vs. $107 \mathrm{~g}$, respectively). Branches from U.S. provenances tended to be slightly larger and heavier than some Danish provenances (Fig. 1), but differences were not significant.

Although the initial moisture content of the branches was higher in 1999 than 2000 , there was no difference in the initial moisture contents of the branches from the farm and forest sites in either year $(161 \%$ vs. $160 \%$, respectively in 1999 and $137 \%$ vs. $139 \%$, respectively in 2000). During both years, there were significant differences in the moisture contents of the U.S. vs. Danish provenances, branches vs. shoots, and display day (Table 2). In 2000 , there was also a significant site $\times$ day $x$ origin interaction. During both years, branches from the U.S. provenances had a small, but significantly higher overall moisture content than the branches from the Danish provenances (94\% vs. 81\%, respectively in 1999 and 104\% and $96 \%$, respectively in 2000). Although the overall moisture levels of the U.S. provenances were significantly higher than Danish provenances, the moisture loss curves for the U.S and Danish provenances were similar during the display test, indicating no differences in the rates of moisture loss for branches from the different sources while on display (Fig. 2). In addition, the patterns of moisture loss from the individual provenances included in these tests indicate that there were no significant differences in the rates of moisture loss between individual U.S. provenances and individual Danish provenances (Data not shown).

During the display period, the branches had a small, but significantly higher overall moisture content than the current-year shoots displayed in the trays. During 1999, the branches had a overall moisture content of $91 \%$ vs. $84 \%$ 


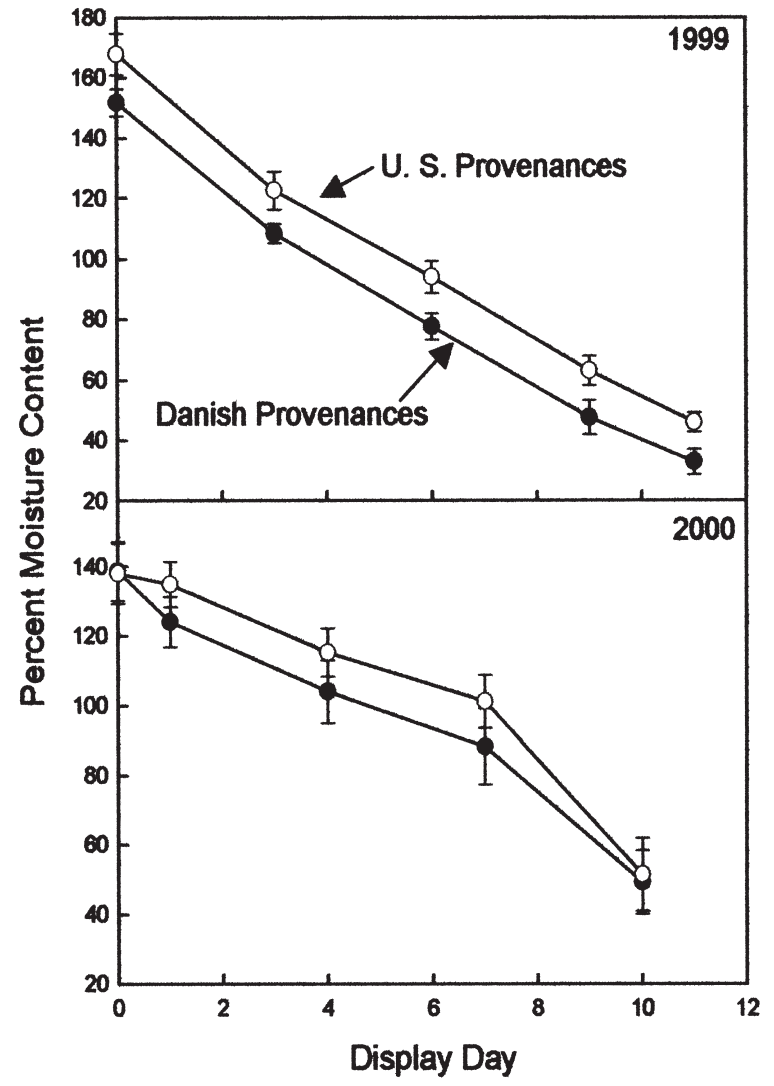

Fig. 2. Drying of two-cross branches from U.S. and Danish provenances of noble fir during 1999 and $2000($ bars = SD).

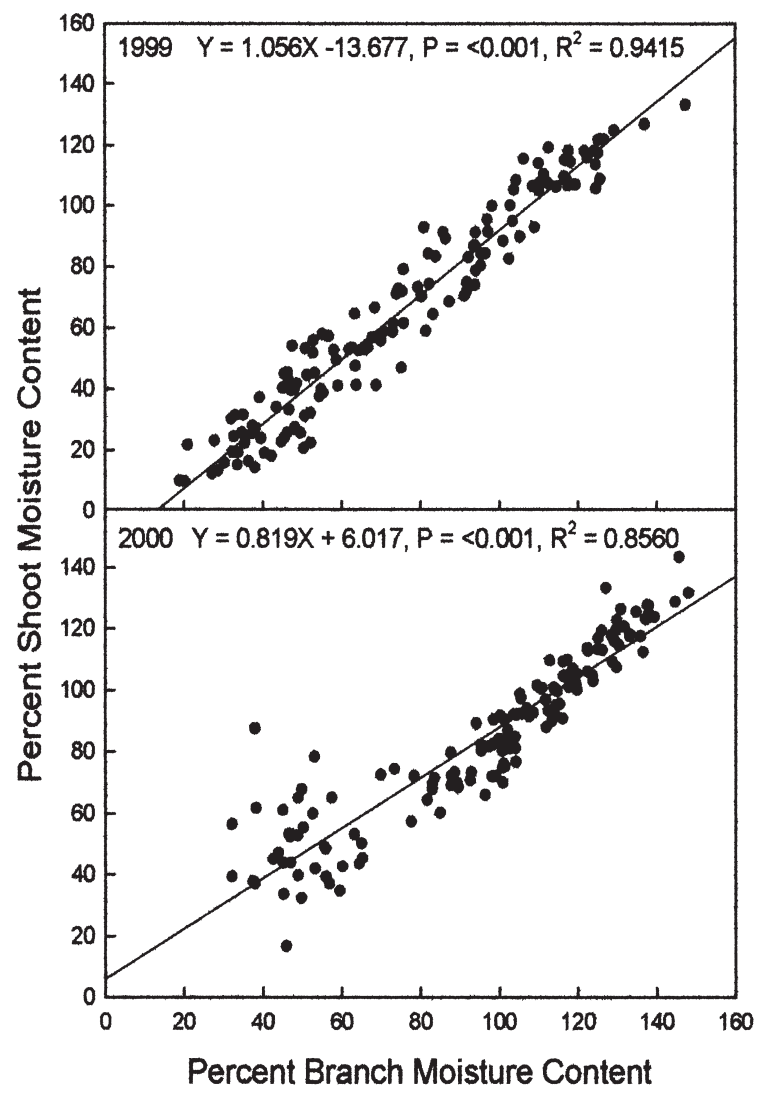

for the shoots; in 2000, $105 \%$ vs. $95 \%$. Even though shoots lost moisture faster than the branches, regression analysis indicates that there was a highly significant linear relationship between the moisture levels of the shoots and the branches during both 1999 and 2000 (Fig. 3).

No needle loss was observed on any of the noble fir branches or shoots during these tests.

\section{Discussion}

At the sites where the noble fir branches were harvested, previous work has shown that the U.S. provenances tend to have faster growth rates and higher levels of CSNN than the Danish provenances (Nielsen, 1999; Nielsen and Christensen, 1995,1997). As a group, the U.S. provenances tended to have slightly larger branches than the Danish sources.

With respect to postharvest characteristics, there appears to be very little difference between the Danish and U.S. provenances. Although differences were observed between the U.S. and Danish provenances with respect to overall moisture provenances with respect to overall mo display, the rate of moisture loss from the branches was similar during these tests.

Temperatures before harvest can affect postharvest needle retention of some Abies spp. (Mitcham-Butler et al., 1988). For example, the ability of fraser fir to develop good postharvest keepability appears to be related to onset of dormancy and acquisition of cold hardiness (MitchamButler et al., 1987). In our study the fall temperatures in Denmark were much higher than normal in September 1999, and about average during September 2000 compared to temperature norms for 1970 to 1990 (Cappelen, 2000; Cappelen and Jørgensen, 2001). In 1999, temperature data from Broholm, which is located about $40 \mathrm{~km}$ from Langes $\varnothing$, indicates that the average temperature between 1 Sept. and when the branches were harvested was $13.3^{\circ} \mathrm{C}$ with a minimum of 10.2 ${ }^{\circ} \mathrm{C}$. In 2000 , temperature data from Langes $\emptyset$ indicated that the average temperature between 1 Sept. and when the branches were harvested was $11.2^{\circ} \mathrm{C}$ with a minimum of $7.7^{\circ} \mathrm{C}$

Even though the trees at the

Fig. 3. Correlation between percent moisture conten of noble fir two-cross branches and current-year shoots. farm and forest sites had not been exposed to cold or frosty temperatures before the dates branches were harvested, no needle loss was observed. Given these results and similar results from recent trials in the PNW (Chastagner, unpublished), it does not appear that needle retention by noble fir is influenced as much by cold hardiness as fraser fir.

Given the high correlation between the moisture level of the branches and shoots, it should be possible to use small shoots to assess differences in moisture retention in future tests. This has the advantage of requiring less space and provides the opportunity to test larger numbers of trees under more controlled conditions. This technique has already been used in a variety of postharvest experiments with fraser fir (Hinesley and Blankenship, 1991; Hinesley and Snelling, 1991)

Although the U.S. provenances that were tested in this study, with the possible exception of no. 89, are not commonly used by Christmas tree growers, results indicate that it is likely that growers who switch from U.S. to Danish provenances of noble fir to reduce the potential for damage from CSNN will not see any reduction in the postharvest quality of the trees they produce. Although the postharvest quality of U.S. and Danish provenances of noble fir appear to be similar, there may be other differences in characteristics such as growth rate and numbers of branches in a whorl that need to be considered before growers switch to noble fir provenances that have not traditionally been grown in their area. Current studies in the PNW indicate that some of the more commonly grown Danish sources of noble fir grow slower than the local sources commonly grown by growers. On some sites, CSNN is not a problem and on many sites the slower growth of the Danish sources may be a bigger problem than low levels of CSNN. Current trials also indicate that at least one faster growing Cascade source of noble fir appears to be as resistant to CSNN as common Danish sources.

\section{Literature Cited}

Barner, H., H. Roulund, and S.Aa. Qvortrup. 1980 Abies procera frøforsyning og proveniensvalg. DST, 65: 263-295.

Brown, K. 1990. A few outstanding noble fir Christmas trees. Christmas Tree Lookout 23(3): 22-23.

Brown, K. and C. Landgren. 1995. Results of the second noble fir Christmas tree provenance test. Christmas Tree Lookout 28(1):10-15.

Cappelen, J. 2000:. The climate of Denmark - Key climatic figures, 1990-99. Danish Meteorol. Inst. Tech. Rpt. 00-08, p47.

Cappelen, J. and B.V. Jørgensen. 2001: Danmarks klima 2000 med tillæg om Færøerne og Grønland. Danmark Meteorologiske Institut Teknisk rapport 01-06, p. 84

Chastagner, G.A. and D.M. Benson. 2000. The Christmas tree: Traditions, production and diseases. Plant Health Progress: Accession DOI 10.1094/PHP-2000-1013-01-2V.

Chastagner, G.A. and K.L. Riley. 2003. Postharvest quality of noble and Nordmann fir Christmas trees. HortScience 38:419-421.

Chastagner, G.A. and C. Landgren. 1998. Genetic variation and the influence of fertilization on the development of current season needle necrosis on noble fir Christmas trees, p. 219-226. In: G. Laflamme, J.A. Berube, and R.C. Hamelin

HortScience Vol. 39(3) June 2004 
(eds.). Foliage, shoot and stem diseases of trees. Proceedings of the IUFRO WP 7.02.02 meeting, Quebec City, 25-31 May 1997. Nat. Resour.Can., Can. For. Serv., Sainte-Foy, Quebec.

Danmarks statistik. 2000. Landbrug 1999, Statistik om landbrug, gartneri og skovbrug. Danmarks Statistiks trykkeri, København.

Davidson, E. 1999. Ten day visit provides revealing snapshot of Irish tree business. Christmas Tree Lookout 32(2):30-32.

Doede, D.L. and W.T. Adams. 1998. The genetics of stemvolume, stem form, and branch characteristics in sapling noble fir. Silvae Genet. 47 (4):177-185.

Douglas, B.S. 1984. How much influence does seed origin have on noble fir growth performance. N.W. Lookout 17(3):16-18.

Frampton, J. and C. McKinley. 1999. Christmas trees and greenery in Denmark-Production and tree improvement. Amer. Christmas Tree J. 43(2):4-11.

Hinesley, L.E. 1984. Measuring freshness of cut fraser fir Christmas trees. HortScience 19:860-862.

Hinesley, L.E. and S.M. Blankenship. 1991. Effect of water additives on fraser fir needle retention. HortTechnology 1:90-91.
Hinesley, L.E and L.K. Snelling. 1991. Vapor pressure deficit, temperature, and light affect postharvest drying of fraser fir and eastern white pine. HortScience 26:402-405

Hinesley, L.E. and L.K. Snelling. 1995. Postharvest drying of Leyland cypress, eastern red cedar, and fraser fir Christmas trees. HortScience 30:1427-1428.

Larsen, J.B. 1985. Økofysiologiske og morfologiske undersøgelser af forskellige Abies procera provenienser med hensyn til deres egnethed til pyntegrøntproduktian (Ecophysiological and morphological investigations of different Abies procera-Provenances in relation to greenery production. Saertryk af Det forstlige Forsøgsvaesen I Danmark 40:175-199.

Mitcham-Butler,E.J.,L.E. Hinesley, and D.M. Pharr. 1988. Effects of harvest date and storage temperature on the postharvest needle retention of fraser fir branches. J. Environ. Hort. 6(1):1-4.

Nielsen, U.B. and C. Christensen. 1995. Røde nåle pånobilis i sommeren 1994. Nwslt. Greenery and Christmas tree production. No. 3.2-4. Danish For. Landscape Res. Inst., Hoersholm, Denmark.

Nielsen, U.B. and C. Christensen. 1997. Røde nåle på nobilis—et tilbagevendende problem. Nwslt. Greenery and Christmas tree production.
No. 3.2-10. Danish For. Landscape Res. Inst., Hoersholm, Denmark.

Nielsen, U.B. 1994. Breeding noble fir (Abies procera Rehder) and nordmann fir (Abies nordmanniana (Stev.) Spach.) for Christmas trees and greenery in Denmark, p. 118-127. In: S.J. Lee (ed.). Proceedings-Nordic Group for Tree Breeding, Edinburgh, Scotland

Nielsen, U.B. 1999. PS plustræfors $\emptyset$ gene i nobilis—vækst og grøntkvalitet-Proveniensvise resultater.Nwslt. Greenery and Christmas tree production. No. 3.2-15. Danish For. Landscape Res. Inst., Hoersholm, Denmark.

Nielsen, C.N., H. Roulund, and J.B. Larsen. 1989 Udsprings-, nålefarve- og vinterfrostresistensunders $\varnothing$ gelser i afkom af nobilisfrøplantagenm FP.623. DST 74:127-145.

Plantedirektoratet. 2001. Kårede frøavlsbevoksningeri Danmarks skove (Approved seed stands in Danish forests). Ministeiet for Fødevarer, Landbrug og Fiskeri, Denmark.

Roulund, H. and J.H. Jensen. 1990. Bedømmelse a plustræudvalg i Nobilis (Abies procera Rehd.) på grundlag af afkomsfors $\varnothing \mathrm{g}$ efter fri afblomstring. DST 75:187-208. 